\title{
Comparison of the phylogenetic analysis of PFGE profiles and the characteristic of virulence genes in clinical and reptile associated Salmonella strains
}

Bartłomiej Dudek', Marta Książczyk', Eva Krzyżewska², Klaudia Rogala², Maciej Kuczkowski³ , Anna Woźniak-Biel ${ }^{3}$, Kamila Korzekwa', Agnieszka Korzeniowska-Kowal ${ }^{2}$, Radosław Ratajszczak ${ }^{4}$, Alina Wieliczko ${ }^{3}$, Jacek Rybka ${ }^{2}$ and Gabriela Bugla-Płoskońska ${ }^{1 *}$ (D)

\begin{abstract}
Background: Salmonella is generally considered as a human pathogen causing typhoid fever and gastrointestinal infections called salmonellosis, with S. Enteritidis and S. Typhimurium strains as the main causative agents. Salmonella enterica strains have a wide host array including humans, birds, pigs, horses, dogs, cats, reptiles, amphibians and insects. Up to $90 \%$ of reptiles are the carriers of one or more serovars of Salmonella. Extraintestinal bacterial infections associated with reptiles pose serious health threat to humans. The import of exotic species of reptiles as pet animals to Europe correlates with the emergence of Salmonella serotypes, which not found previously in European countries. The presented study is a new report about Salmonella serotypes associated with exotic reptiles in Poland. The goal of this research was to examine the zoonotic potential of Salmonella strains isolated from reptiles by comparative analysis with $S$. Enteritidis strains occurring in human population and causing salmonellosis.
\end{abstract}

Results: The main findings of our work show that exotic reptiles are asymptomatic carriers of Salmonella serovars other than correlated with salmonellosis in humans (S. Enteritidis, S. Typhimurium). Among the isolated Salmonella strains we identified serovars that have not been reported earlier in Poland, for example belonging to subspecies diarizonae and salamae. Restriction analysis with Pulsed-field Gel Electrophoresis (PFGE), showed a great diversity among Salmonella strains isolated from reptiles. Almost all tested strains had distinct restriction patterns. While $S$. Enteritidis strains were quite homogeneous in term of phylogenetic relations. Most of the tested VGs were common for the two tested groups of Salmonella strains.

Conclusions: The obtained results show that Salmonella strains isolated from reptiles share most of virulence genes with the $S$. Enteritidis strains and exhibit a greater phylogenetic diversity than the tested $S$. Enteritidis population.

Keywords: Salmonella, RAS, PFGE profiles, Zoonotic potential

\footnotetext{
* Correspondence: gabriela.bugla-ploskonska@uwr.edu.pl

${ }^{1}$ Department of Microbiology, Faculty of Biological Sciences, University of

Wrocław, 51-148 Wrocław, Poland

Full list of author information is available at the end of the article
}

(c) The Author(s). 2019 Open Access This article is distributed under the terms of the Creative Commons Attribution 4.0 International License (http://creativecommons.org/licenses/by/4.0/), which permits unrestricted use, distribution, and reproduction in any medium, provided you give appropriate credit to the original author(s) and the source, provide a link to the Creative Commons license, and indicate if changes were made. The Creative Commons Public Domain Dedication waiver (http://creativecommons.org/publicdomain/zero/1.0/) applies to the data made available in this article, unless otherwise stated. 


\section{Background}

Salmonella is a Gram-negative bacteria responsible for a wide variety of infectious diseases: typhoid fever, gastroenteritis, food poisoning and septicaemia. Multiple genes required for full virulence of Salmonella strains are encoded on Salmonella pathogenicity islands (SPI) and could be acquired by horizontal transfer from other organisms. Infections, caused by nontyphoidal Salmonella strains (NTS), are recorded worldwide (94 million cases/ year) but the epidemiological data are probably underestimated as many milder cases are neither diagnosed nor reported [1]. Currently, there are more than 2600 Salmonella enterica serovars [2] identified up to date. Salmonella enterica subsp. enterica Enteritidis (S. Enteritidis) is the most commonly isolated serovar in Europe. Although the number of cases of salmonellosis has been decreasing for over a dozen of years, the epidemiological data from Poland indicate a significant increase of Salmonella gastrointestinal infections in 2017. The National Institute of Public Health reported 8652 cases of Salmonella infections in 2015 and 10,007 cases in 2017 [3]. A multitude of publications worldwide indicate the specific virulence of $S$. Enteritidis and its ability to induce acute systemic infections, that often lead to death of the patient [4-7]. Roll et al. reported a case of transplacental infection of a premature infant by NTS in a woman with diarrhea and fever. In the 29th week of pregnancy, after a caesarean section, the newborn died from a septic shock. The same $S$. Enteritidis strain was cultured from blood cultures of the premature infant and from samples collected from the mother (placenta, uterus) [5]. Pumberger and Novak reported a case of a lethal infection of a newborn caused by NTS. One day after the birth, the condition of the newborn has deteriorated rapidly, acute abdominal inflammation and bloody diarrhea occurred. During epidemiological investigation the same $S$. Enteritidis strain has been cultured from maternal vaginal and fecal swabs, which clearly indicated the vertical transmission of the $S$. Enteritidis during childbirth [4].

Salmonella enterica strains have a wide host range including humans, birds, pigs, horses, dogs, cats, reptiles, amphibians and insects [8]. Up to $90 \%$ of reptiles are the carriers of one or more serovars of Salmonella, rarely demonstrating symptoms of any disease [9-11]. The disease can develop as a result of stress, exposure to low ambient temperatures or a sudden change of diet.

A large number of human salmonellosis cases have been linked to zoonotic transmission from snakes, turtles, lizards and terrapins [12-15]. Reptile-associated salmonellosis (RAS) is a serious health problem, especially in countries where reptiles are kept as pets, and is usually recorded in children under 5 years of age and people with immunodeficiency [16]. Recently the term reptile-exotic-pet associated salmonellosis (REPAS) is used instead of RAS, as salmonellosis can be more and more often caused by the contact with exotic species of reptiles imported to Europe from other parts of the world rather than by the contact with native species $[16,17]$. Most data about RAS come from the USA but this new epidemiological problem starts to affect more and more countries. The number of RAS cases in USA is about 74,000 per year. A study published in 2013, shows an upward trend in the number of RAS cases in children under 3 years of age in countries of the European Union in 2007-2010 [17]. Van Meervenne et al. reported a case of RAS in a 2-month-old baby which led to sepsis and meningitis [13]. Also Schneider et al. described a case of RAS in a 10-month-old baby which leads to septic arthritis [14]. There are also cases of RAS reported in adults [15]. S. arizonae, S. diarizonae, S. houtenae, S. Java, $S$. Poona, S. Pomona, S. Stanley, S. Minnesota and $S$. Chameleon are the most commonly reported Salmonella strains encountered in RAS $[9,18]$.

Subspecies S. houtenae, S. arizonae and S. diarizonae belong to the somatic group O48 which have been previously shown to contain sialic acid (NeuAc) in the O-specific polysaccharide [19-21]. NeuAc is an important component of the bacterial cell wall because of the participation in the phenomenon of molecular mimicry. Salmonella strains belonging to the O-antigen somatic group $\mathrm{O} 48$ are described in the literature as an important etiological factor causing acute gastroenteritis in children [22, 23]. The presence of sialylated structures on the bacterial cell surface is a part of defense mechanism against the host immune system [24-26]. In our previous studies we investigated the role of lipopolysaccharide and outer membrane proteins of Salmonella O48 strains in the generation of serum resistance [27-29].

The analysis of Salmonella strains isolated from exotic reptiles are not frequent in Poland [30,31]. The aim of this study was the examination of the prevalence of Salmonella strains isolated from different species of reptiles and the determination of their potential of pathogenicity and the comparison with the strains occurring in human population in Poland. Isolated Salmonella strains were screened for the presence of sialic acid in the lipopolysaccharide molecule. The study aimed also to compare the potential virulence of these strains by determining the genetic diversity of virulence genes of already extensively distributed $S$. Enteritidis strains isolated from humans and Salmonella strains isolated from reptiles, which may be associated with an epidemiological problem.

Zoological gardens with exotic animals species are often involved in education in the field of species protection, including the protection of biological diversity. The zoological garden in Wrocław participates, among others, in the program of research and protection of the 
Komodo dragons in the Wae Wuul nature reserve situated on the west coast of the island of Flores in Indonesia. Reptile microbial research, as a part of biological biodiversity studies, indicates the importance of public knowledge in the context of epidemiological threats resulting from breeding reptiles at home. In this case the cooperation between zoological gardens and scientists turned out to be very fruitful.

\section{Results}

\section{Identification of bacterial strains}

Bacterial strains used in this study were assigned to Salmonella genus with the following methods: biochemical tests, MALDI-TOF MS analysis and 16S rRNA sequencing.

All tested bacterial strains were classified as Salmonella enterica group with $98.32-100 \%$ sequence similarity. MALDI-TOF MS identified the tested bacterial samples as Salmonella species. All thirty strains assigned as Salmonella were additionally serotyped and classified according to the Kauffmann-White-Le Minor scheme (Table 1).

\section{Virulence genotyping}

Results of virulence-associated genes (VGs) are presented in Fig. 1 and Additional file 1. Determined VGs profiles for both: $S$. Enteritidis from humans and Salmonella strains from reptiles, revealed differences in the prevalence of virulence genes. Salmonella strains from humans showed higher prevalence of VGs in comparison to reptilian Salmonella strains. The comparison of percentage prevalence of VGs among both investigated groups of Salmonella strains is presented in Fig. 2.

Following virulence genes were detected in genomes of all tested $S$. Enteritidis strains: $\operatorname{sip} B, \operatorname{prgH}, \operatorname{spaN}, \operatorname{org} A$, tolC, sitC, lpfC, sifA, sopB, pefA, spvB, spiA, pagC and msgA. 93\% of human Salmonella strains possessed invA gene and $53 \%$ of these strains had iroN gene. No one of the tested $S$. Enteritidis strains had the $c d t B$ gene.

All Salmonella strains (100\%) isolated from reptiles possessed in their genomes following virulence genes: $\operatorname{prgH}$, orgA, tolC, sitC, spiA and msgA like as among $S$. Enteritidis strains. Also $53 \%$ of reptilian Salmonella strains had iroN gene like in the tested $S$. Enteritidis strains. The prevalence of $\operatorname{inv} A$ (33\%), sipB (80\%), spaN (47\%), lpfC (27\%), sifA (20\%), sopB (87\%), pagC (80\%) was lower than among human strains. Gene $c d t B$, which was not present in $S$. Enteritidis strains, was detected in $40 \%$ of reptilian Salmonella strains. However none of the tested Salmonella strains isolated from reptiles had spvB and pefA genes in its genome. Strains PCM 2942, PCM 2944, PCM 2956 and PCM 2952 belong to the same subspecies: Salmonella diarizonae, but all of these four strains had different VGs profiles. Strains PCM
Table 1 Tested Salmonella strains

\begin{tabular}{|c|c|c|}
\hline $\begin{array}{l}\text { Number of } \mathrm{PCM}^{\mathrm{a}} \\
\text { strain }\end{array}$ & Origin & $\begin{array}{l}\text { Salmonella enterica } \\
\text { taxonomic classification }\end{array}$ \\
\hline 2817 & human feces & Enteritidis \\
\hline 2935 & human feces & Enteritidis \\
\hline 2814 & human feces & Enteritidis \\
\hline 2936 & human feces & Enteritidis \\
\hline 2812 & human feces & Enteritidis \\
\hline 2937 & human feces & Enteritidis \\
\hline 2808 & human feces & Enteritidis \\
\hline 2810 & human feces & Enteritidis \\
\hline 2811 & human feces & Enteritidis \\
\hline 2938 & human feces & Enteritidis \\
\hline 2939 & human feces & Enteritidis \\
\hline 2940 & human feces & Enteritidis \\
\hline 2815 & human feces & Enteritidis \\
\hline 2941 & human feces & Enteritidis \\
\hline 2816 & human feces & Enteritidis \\
\hline $2942^{\mathrm{b}}$ & $\begin{array}{l}\text { Flat-headed rock agama } \\
\text { (Agama mwanzae) }\end{array}$ & diarizonae 61: c: z35 \\
\hline 2943 & $\begin{array}{l}\text { Common collared lizard } \\
\text { (Crotaphytus collaris) }\end{array}$ & Muenchen (O8) \\
\hline $2944^{b}$ & $\begin{array}{l}\text { Baja blue rock lizard } \\
\text { (Petrosaurus thalassinus) }\end{array}$ & diarizonae $65: \mathrm{k}: \mathrm{z}$ \\
\hline $2945^{b}$ & $\begin{array}{l}\text { Leopard gecko } \\
\text { (Eublepharis macularius) }\end{array}$ & salamae 30: 1, z28: z6 \\
\hline 2946 & $\begin{array}{l}\text { Red-headed rock agama } \\
\text { (Agama agama) }\end{array}$ & Hvittingfoss (O16) \\
\hline $2947^{\mathrm{b}}$ & $\begin{array}{l}\text { Western bearded anole } \\
\text { (Anolis barbatus) }\end{array}$ & 16: $\mathrm{m}, \mathrm{t}:-$ \\
\hline 2948 & $\begin{array}{l}\text { Radiated tortoise } \\
\text { (Astrochelys radiata) }\end{array}$ & Amsterdam (O3) \\
\hline $2949^{b}$ & $\begin{array}{l}\text { Central bearded dragon } \\
\text { (Pogona vitticeps) }^{c}\end{array}$ & salamae 40: $\mathrm{g}, \mathrm{m}$, t: - \\
\hline 2950 & $\begin{array}{l}\text { Eastern kingsnake } \\
\text { (Lampropeltis getula) }\end{array}$ & Adelaide (O35) \\
\hline 2951 & $\begin{array}{l}\text { Leopard tortoise } \\
\text { (Psammobates pardalis) }\end{array}$ & salamae 18: z4, z23: - \\
\hline 2952 & $\begin{array}{l}\text { Garter snake } \\
\text { (Thamnophis sp.) }\end{array}$ & diarizonae 53: z 10: z35 \\
\hline 2953 & $\begin{array}{l}\text { Chinese water dragon } \\
\text { (Physignathus cocincinus) }\end{array}$ & Virchow (O7) \\
\hline 2954 & 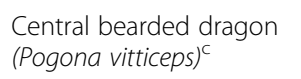 & Kaneshie (O42) \\
\hline 2955 & $\begin{array}{l}\text { Marginated tortoise } \\
\text { (Testudo marginata) }\end{array}$ & Amsterdam (O3) \\
\hline 2956 & $\begin{array}{l}\text { Central bearded dragon } \\
\text { (Pogona vitticeps) }^{c}\end{array}$ & diarizonae 6: r: z \\
\hline
\end{tabular}

a Polish Collection of Microorganisms (PCM)

${ }^{b}$ Salmonella serovars first time isolated in Poland (based on available data) [31-34]

c Salmonella strains isolated from the same animal 


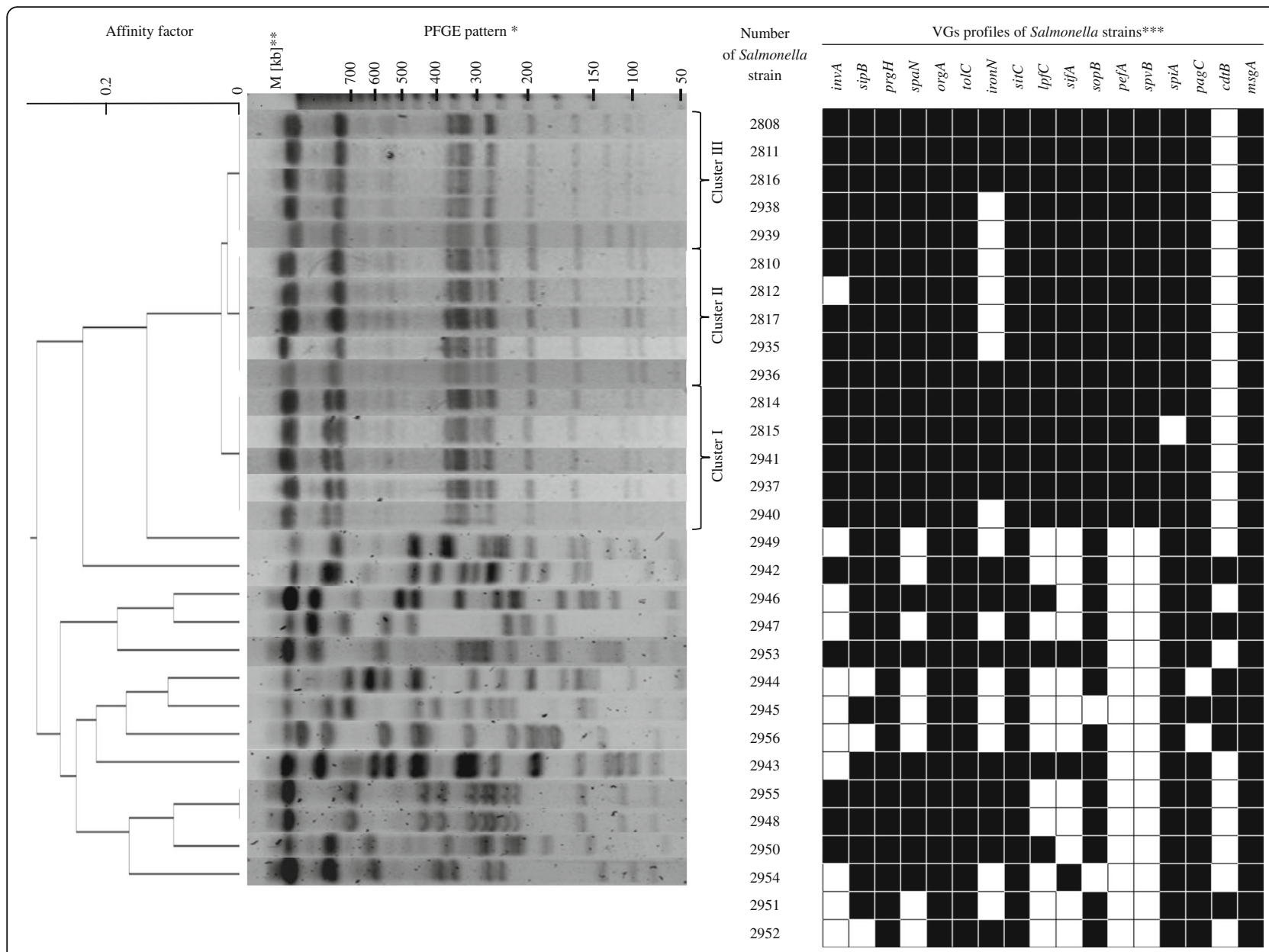

Fig. 1 Genetic relatedness and VGs profiles of Salmonella strains isolated from humans and reptiles. * Strains PCM 2951 and PCM 2952 were nontypeable with PFGE method. ** Molecular Weight Marker. *** White square - lack of virulence gene, black square - presence of virulence gene

2945, PCM 2949 and PCM 2951 were assigned to subspecies Salmonella salamae and their VGs profiles were similar with slight differences, strains PCM 2948 and PCM 2955 - both S. Amsterdam - had identical VGs profiles.
Analysis of the restriction profiles connected with Pulsed-field Gel Electrophoresis (PFGE) revealed that tested $S$. Enteritidis population is quite homogeneous in term of phylogenetic relations (results presented on Fig. 1). At the PFGE phylogenetic dendrogram human

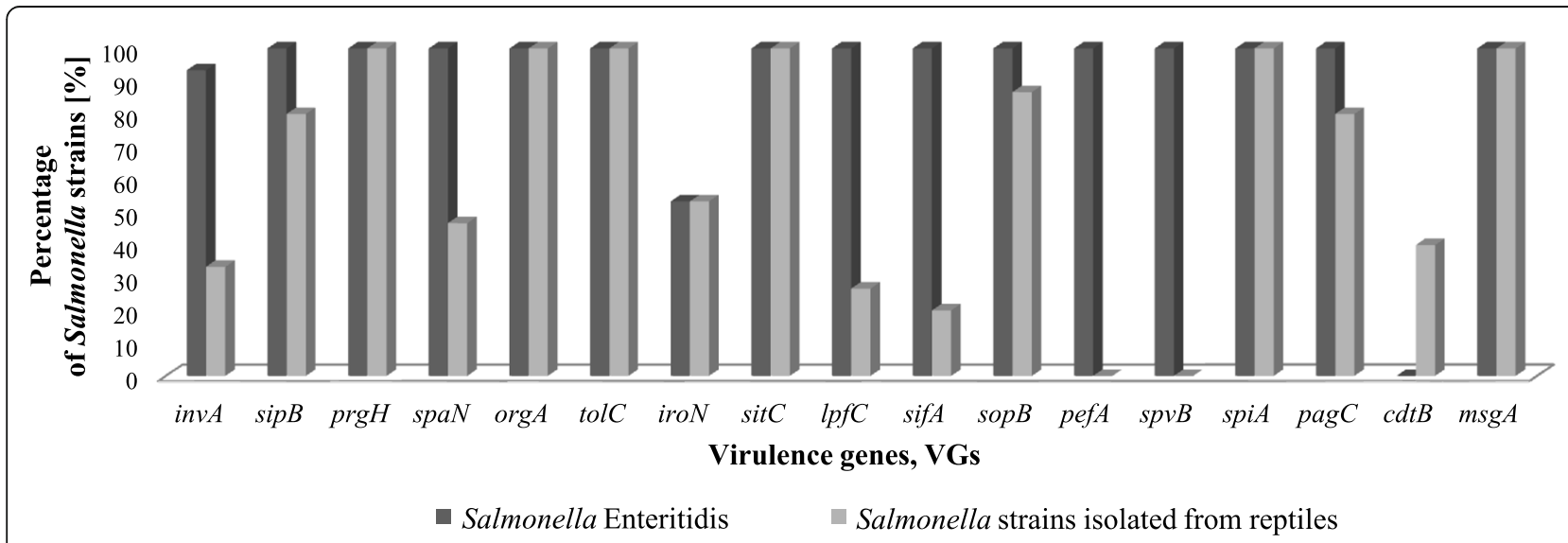

Fig. 2 Percentage layout of detected VGs among Salmonella strains isolated from humans and reptiles 
Salmonella strains are divided into three clusters. Among the strains in each cluster there are few slight differences in their VGs profiles (Fig. 1). In cluster I, the main VGs pattern was: invA+, sipB+, $p r g H+$, spa $N_{+}$, $\operatorname{org} A+$, tolC+, iro $N+$, sitC+, lpfC+, sif $A+$, sop $B+$, pef $A+$, spvB+, spiAt, pagC+, cdtB- and msgAt, however strain PCM 2940 was lacking one gene more iroN. In cluster II the leading VGs pattern is: $i n v A+$, sipB+, $p r g H+$, spaN+, $\operatorname{org} A+$, tolC+, iroN -, sit $C+$, lpfC+, sif $A+$, sop $B+$, pef $A+$, $s p v B+$, spiA+, pagC+, $c d t B-$ and $m s g A+$, but strain PCM 2812 was additionally lacking $i n v A$ gene and strain PCM 2936 had in genome gene iroN. In cluster III, the strains PCM 2816, PCM 2808 and PCM 2811 had following VGs profiles: $i n v A+, \operatorname{sip} B+, \operatorname{prg} H+, \operatorname{spaN}+, \operatorname{org} A+, t o l C+$, iroN +, sit $C+, \operatorname{lpf} C+$, sif $A+$, sop $B+$, pef $A+$, spv $B+$, spi $A+$, pag $C+$, $c d t B$ - and $m s g A+$. Strains PCM 2938 and PCM 2939 from cluster III was lacking iroN gene in comparison to strains PCM 2816, PCM 2808 and PCM 2811.

\section{Analysis of the phylogenetic relationship}

Analysis of the restriction profiles of Salmonella strains isolated from reptiles revealed a great diversity among bacterial strains. Strains PCM 2951 and PCM 2952 were nontypeable with PFGE method, no restriction pattern of these strains were obtained despite of carrying out several experiments. Only two strains: PCM 2955 and PCM 2948 of the same serotype - S. Amsterdam, showing the same pattern of restriction, had also the same VGs profile: $i n v A+$, $\operatorname{sip} B+, \operatorname{prg} H_{+}, \operatorname{spaN+}$, orgA+, $\operatorname{tol} C_{+}$, iroN +, sitC+, lpfC-, sifA-, sop $B+$, pefA-, spvB-, spiA+, $p a g C+, c d t B$ - and $m s g A+$. These fact indicate that strains PCM 2948 and PCM 2955 could be the same bacterial clone. Other Salmonella strains isolated from reptiles showed various patterns of restriction fragments and also had different VGs profiles (Fig. 1). Strains belonging to the subspecies S. diarizonae: PCM 2942 and PCM 2944, S. salamae: PCM 2945 and PCM 2949 had distant positions on the obtained phylogenetic tree. Three of reptilian Salmonella strains: PCM 2949, PCM 2954 and PCM 2956, isolated from the same animal (Pogona vitticeps), had completely different PFGE restriction profiles and differed also in VGs patterns. We did not observed any similarity between restriction profiles of Salmonella strains isolated from humans and reptiles.

\section{GLC MS/MS analysis}

Gas-liquid chromatography/tandem mass spectrometry analysis (GLC-MS/MS) of NeuAc content was performed in the preparations of whole bacteria. In this study the presence of NeuAc in bacterial cells in minimal medium were analyzed. All tested Salmonella strains were NeuAc negative. Figure 3 shows exemplary chromatograms of two samples: the control sample of $H$. alvei PCM 2386 with confirmed presence of NeuAc in the LPS structure [35] and one of the tested strains: Salmonella PCM 2946.

\section{Discussion}

Salmonella as a pathogen is usually connected with gastrointestinal infection, often of zoonotic origin mainly from wild or breeding birds. Our previous studies confirmed that the outer membrane structures of $S$. Enteritidis strains exhibiting high serum resistance play a crucial role in that phenomenon [36]. We have also shown, that these strains produce very long O-specific chain in LPS structure along with specific outer membrane proteins, what enhanced their pathogenicity [36]. Another studies have shown that some Salmonella O48 strains, which are frequently isolated from reptiles, use special virulence strategy predisposing them to the development of severe extraintestinal infection [37]. In the present work we analyzed the level of pathogenicity and phylogenetic structure of Salmonella strains isolated from reptiles with $S$. Enteritidis strains isolated from humans.

S. Enteritidis is a common foodborne pathogen, disseminated worldwide. The incidence of $S$. Enteritidis infections was increasing very fast in the 1990s and is now the most frequently reported Salmonella serovar around the world [38]. However, the number of reptileassociated Salmonella infections, often with fatal outcome, has been increasing together with popularity of handling reptiles as domestic pets [39]. Research focused on RAS were conducted e.g. in USA [40-42], Korea [43], Mexico [8, 44] or Malaysia [45]. The issue of reptiles as a reservoir of pathogenic Salmonella strains has been examined also in Europe, e.g. in Germany [17], Italy [46, 47], UK [48] or Sweden [49] where for years the Salmonella controlling and preventing program included special restrictions towards Salmonella strains originating from reptiles [50].

There are not many reports about Salmonella strains isolated from reptiles in Poland and the epidemiology of RAS/REPAS strains is unexplored and unknown. The presented study is one of the initial works about this epidemiological situation, connected with prevalence of Salmonella strains among exotic reptiles present in Poland. The majority of the research related with Salmonella strains isolated from reptiles include reptiles as domestic pets or wild reptiles free-living in Poland [30, 31], but in our research Salmonella strains were isolated from exotic reptiles belonging to the collection of Zoo in Wrocław, Poland. Reptiles in zoos often come from a custom control that capture smuggled and illegally imported animals taken from their natural environment. Salmonella serovars and other bacterial strains isolated from gastrointestinal tract of reptiles dwelled in zoos, 

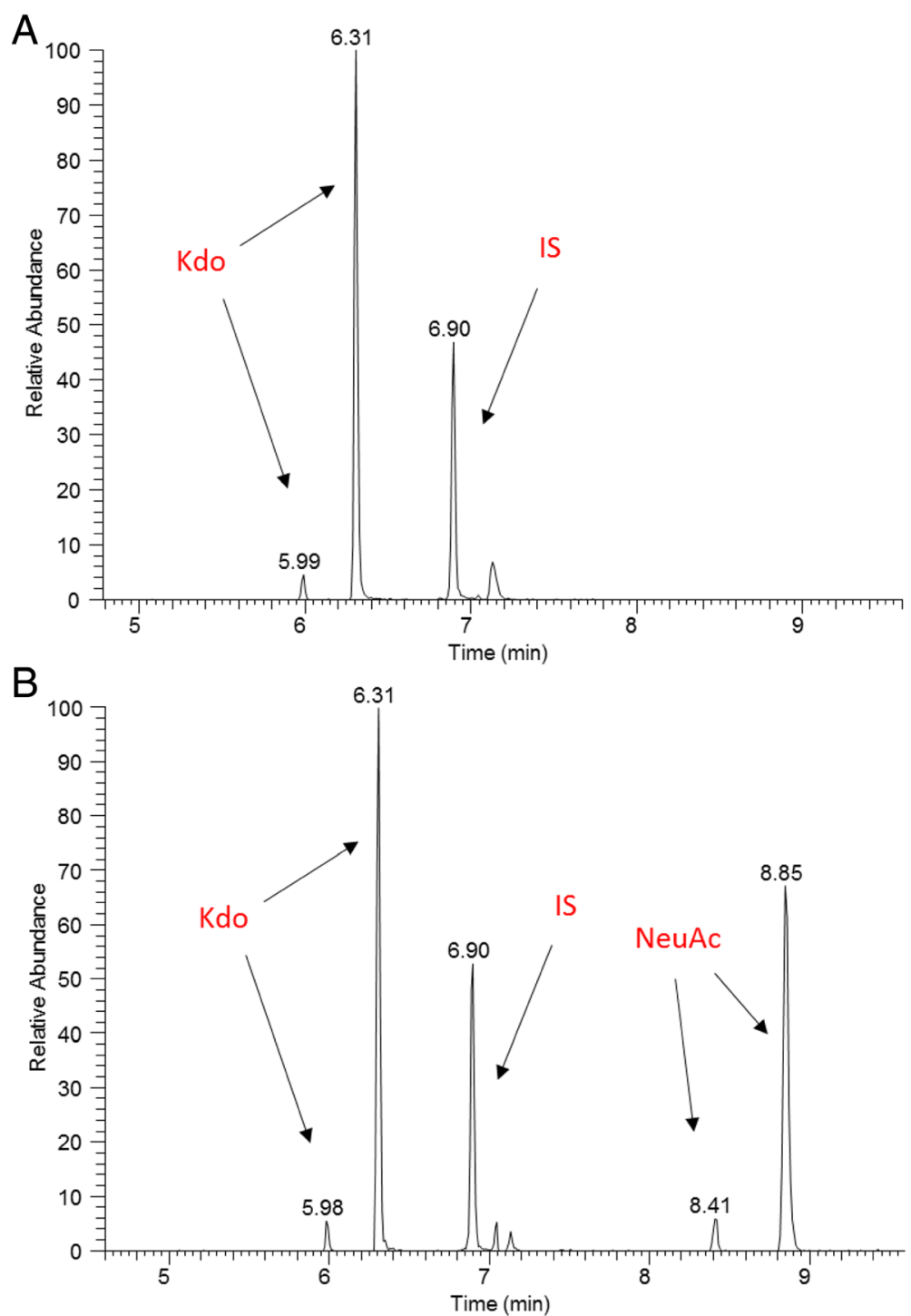

Fig. 3 GLC-MS/MS analysis of NeuAc (sialic acid) content. a Tested Salmonella Hvittingfoss PCM 2946 strain; b Control: Hafnia alvei PCM 2386. MS/ MS simultaneous analysis of Kdo (marker ion of $\mathrm{m} / \mathrm{z}=195$ ), NeuAc (ion of $\mathrm{m} / \mathrm{z}=386$ ), and perseitol (ion of $\mathrm{m} / \mathrm{z}=128$ ) as an internal standard (IS)

could have an endemic character, being not previously reported in European countries.

Our results confirmed that exotic reptiles are common, asymptomatic carriers of Salmonella strains. From 84 samples collected from reptiles dwelled in Wrocław Zoo we isolated 15 Salmonella strains. Among them 4 isolated strains belonged to Salmonella enterica subsp. diarizonae and 3 to Salmonella enterica subsp. salamae. These Salmonella serovars are not typical for European region and have been imported together with reptiles from their exotic, native countries.

In the investigation of Piasecki et al. [30] Salmonella were found in 122 of 374 samples (32.6\%). This research was focused on the occurrence of Salmonella strains in the natural microflora of exotic reptiles residing in
Poland (zoos or private keepers). Also Zając et al. [31] determined the prevalence of Salmonella and other bacteria among 16 dead free-living snakes found in central Poland. Salmonella strains were detected in $87.5 \%$ of the tested animals what included 33 bacterial isolates representing 11 Salmonella serovars. The most frequent isolated serovars were Salmonella enterica subsp. diarizonae (IIIb) $(n=9)$ and Salmonella enterica subsp. enterica $(n=2)$ [31].

Results obtained in current paper are consistent with other research reports $[10,18,49]$. Similarly as in study carried out in Zagreb Zoo between 2009 and 2011 [10] Salmonella serovars typical for exotic countries, identified in Poland for the first time, belonging to subspecies diarizonae and salamae [32-34]. Moreover Wikström 
et al. isolated S. enterica subsp. diarizonae strains and $S$. enterica subsp. enterica Fluntern [49], which are occasionally isolated from reptiles but not detected in our study. In Antwerp Zoo in Belgium reptiles were carriers of S. salamae, S. diarizonae, S. arizonae and S. houtenae [51]. The team of Schröter revealed that about $81 \%$ of the tested snakes harbored various serovars of $S$. enterica subsp. diarizonae [18]. All these results confirm, that reptiles serve nowadays as vectors spreading exotic Salmonella serovars in new ecological niches including Europe.

Moreover, the comparative analysis of two Salmonella diarizonae strains isolated from invasive infections of humans, revealed that this Salmonella serotype pose a huge health-risk, as Giner-Lamia et al. [52] identified in genomes of $S$. diarizonae strains a number of genes responsible for high virulence.

In the present study we isolated from reptiles Salmonella serovars, which are well-known as human pathogens, such as $S$. Virchow, $S$. Amsterdam, $S$. Muenchen; that could be connected with the transmission of bacterial strains from humans to reptiles. Pedersen et al. [53] isolated $S$. Enteritidis and $S$. Typhimurium, which are commonly isolated from humans and often cause food contamination. In other studies $S$. Enteritidis, $S$. Typhimurium, $S$. Newport, $S$. Muenchen, $S$. Java and $S$. Pomona were reported as RAS/REPAS [39].

In the GLC-MS/MS analysis we did not detect the presence of NeuAc in the LPS structure among the tested Salmonella strains isolated from reptiles, what indicates, that none of these strains belonged to the $\mathrm{O} 48$ group.

Restriction analysis with PFGE, carried out during the presented work, showed a great diversity among Salmonella strains $(n=13)$ isolated from reptiles. Almost all tested strains had distinct restriction patterns, only two strains of Salmonella Amsterdam isolated from two different animals: Marginated tortoise (Testudo marginata) and Radiated tortoise (Astrochelys radiate) had completely the same PFGE profile. Probably it is a result of sharing the same bacterial flora between animals kept together, as transmission of Salmonella strains could occur via the faces in the water or food. Pees et al. [17] analyzed the phylogenetic structure of Salmonella strains isolated from reptiles kept in households in Germany with PFGE method. In that study PFGE profiles, obtained for all tested strains, were also diverse and the dominant PFGE type was not found as in our research [17].

Frequently one animal could carry more than one Salmonella serovar [54]. Zając et al. have found four different Salmonella serovars in a single snake [31]. Also in our study we have identified three various Salmonella serovars in one tested animal - Central bearded dragon
(Pogona vitticeps). It is another reason why reptiles are efficient vectors for Salmonella strains: these animals are asymptomatic carriers even for more than one pathogenic bacterial strain, each of them can be easily transmitted to humans. Moreover, carrying several Salmonella serovars by one reptile could lead to an exchange of genetic material by horizontal gene transfer [55] what enhances the pathogenicity of Salmonella strains by an acquisition of new virulence genes or other genetic factors.

In the present project we compare Salmonella strains isolated from reptiles with $S$. Enteritidis isolated from humans with gastrointestinal disease. The results of PFGE analysis showed that tested $S$. Enteritidis strains are divided in three clusters. Minor differences in restriction patterns could be the result of genetic rearrangements that enables strains for adaptation to host organism and enhance their pathogenicity. However, the dominant PFGE types of $S$. Enteritidis in our study are similar to the dominant PFGE patterns obtained in analysis of clinical and environmental $S$. Enteritidis strains isolated in different parts of the world, e.g. Turkey, United States or Canada and Morocco [38, 56, 57].

Almost all known virulence genes (VGs), which are very significant in Salmonella pathogenicity were detected in all tested $S$. Enteritidis strains. Such a set of virulence genes enhance the successful host invasion, colonization and disease development, what could be a reason of worldwide dissemination of $S$. Enteritidis as the most frequently isolated clinical Salmonella serovar.

Salmonella strains isolated from reptiles show also high prevalence of tested VGs. Presented paper is the first study, where 17 virulence genes, typical for Salmonella, were detected among strains isolated from reptiles. Our studies indicate that $S$. Enteritidis strains have a high level of VGs presence, but none of the strains have the $c d t B$ (host recognition/invasion) gene, which occurs in several Salmonella isolates from reptiles. On the other hand, none of the Salmonella strains isolated from reptiles have $\operatorname{spv} B$ (growth within host) and pefA (host recognition/invasion) genes, which occurs in all strains of $S$. Enteritidis. Skyberg et al. [58] determined the prevalence of these 17 VGs among Salmonella strains isolated from healthy birds $[n=80]$ and also from birds with infection $[n=76]$. Results obtained by Skyberg's group revealed, that all of tested bacterial strains from both groups of birds had following VGs: spiA, pagC, $m s g A$, invA, sipB, prgH, spaN, orgA, tolC, iroN, sitC. Krawiec et al. [59] had used the same VGs set and determined its prevalence among Salmonella strains isolated from wild birds in Poland. In all isolated $S$. Typhimurium strains Krawiec at al. found following genes: spiA, $m s g A$, invA, lpfC and sifA, additionally $94.45 \%$ of the tested bacterial isolates carried also the $\operatorname{sit} C$ and $\operatorname{sop} B$ virulence genes. 
Our research showed that clinical strains of $S$. Enteritidis, which are the most common cause of salmonellosis throughout Europe, are not genetically homogeneous, we obtained three different genomic clusters for the tested $15 \mathrm{~S}$. Enteritidis strains. The obtained results revealed the continuous adaptation of $S$. Enteritidis to the environment. In the presented study we proved that all tested $S$. Enteritidis strains have almost all tested virulence genes which are important from the point of infection.

The presence of a large number of virulence genes predisposes $S$. Enteritidis to be the most commonly isolated clinical strain in Europe. Nevertheless the tested Salmonella strains isolated from reptiles also show a wide diversity of the detected virulence genes.

\section{Conclusions}

Exotic reptiles in Europe, can work as vectors introducing new strains of dangerous bacteria to the environment. Such bacteria could be recognized as a new, important epidemiological factor, very distinct from local endemic bacterial flora, especially in the face of widespread trade of reptiles around the world, and their presence in our household as pets. Our findings also highlight, that the knowledge about microflora of reptiles and appropriate hygienic conditions should be recommended for handling of reptiles. In addition, prevention of human infections requires proper education about personal hygiene. In comparison to $S$. Enteritidis, Salmonella strains isolated from reptiles are definitely more heterogeneous in phylogenetic view. S. Enteritidis as common and prevalent pathogen has few genetic patterns and is quite homogeneous.

\section{Methods}

\section{Bacterial strains}

The study was carried out on 15 clinical $S$. Enteritidis strains isolated from the feces of humans with symptoms of diarrhea in years 2012-2013 in Dialab Laboratory, Wrocław, Poland and 15 Salmonella strains isolated from feces of healthy reptiles from the Zoological Garden in Wrocław, Lower Silesia in Poland in years 2011-2014. All Salmonella strains used in this study were deposited in the Polish Collection of Microorganisms (PCM).

\section{Growth conditions}

For genetic assays, the bacteria were cultured overnight at $37^{\circ} \mathrm{C}$ in Lysogeny Broth (LB) or nutrient agar (Biocorp). For gas-liquid chromatography mass spectrometry analysis (GLC-MS), the bacteria were cultivated in minimal medium $\left[\mathrm{K}_{2} \mathrm{HPO}_{4}, \mathrm{KH}_{2} \mathrm{PO}_{4}, \mathrm{MgSO}_{4},\left(\mathrm{NH}_{4}\right)_{2} \mathrm{SO}_{4}\right.$, glucose, and $\mathrm{NaCl}$ (POCh, Poland)] needed in GLC-MS analysis.

\section{Identification of presumptive Salmonella strains with conventional methods}

Salmonella strains were identified, using biochemical tests and serotyping with specific $\mathrm{O}$ and $\mathrm{H}$ antisera, and classified according to the Kauffmann-White-Le Minor scheme [2]. Serotyping of Salmonella strains isolated from reptiles was performed in the National Veterinary Research Institute (Puławy, Poland) and National Salmonella Centre (Gdańsk, Poland). A complete list of the tested strains is presented in Table 1.

\section{Identification with mass spectrometry methods Sample preparation for MALDI-TOF MS analysis}

Bacterial sample were prepared according to the manufacturer's protocol (BrukerDaltonics, USA). Shortly: two to five bacterial colonies were suspended in water and precipitated with ethanol. After drying, equal volumes of $70 \%$ formic acid and acetonitrile were added and, after centrifugation, $1 \mu \mathrm{l}$ of supernatant was transferred to ground steel MALDI plate for analysis, with $\alpha$-cyano-4hydroxy-cynnamic acid in 50\% ethanol with 2,5\% TFA used as a matrix. Identification of bacterial strains using MALDI-TOF MS Biotyper was conducted with the application of ultraflExtreme (BrukerDaltonics, USA). Spectra were recorded in the positive linear mode for a mass range of 2000-20.000 Da. Each spectrum was obtained by averaging 600 laser shots acquired from the automatic mode under control of FlexControl software ver. 3.4 (BrukerDaltonics, USA). The spectra were externally calibrated using an $E$. coli DH5-alpha standard (BrukerDaltonics, USA). Biotyper ver. 3.1 (MSP 4613) database software (BrukerDaltonics, USA) was used for the identification of bacterial isolates.

\section{Molecular identification of Salmonella isolates DNA extraction}

Bacterial DNA was extracted using commercially available Genomic Mini Kit (A\&A Biotechnology, Poland) according to the manufacturer's protocol from overnight $\left(18-24 \mathrm{~h}, 37^{\circ} \mathrm{C}\right)$ culture.

\section{5 rRNA identification}

To amplify the entire $~ 1500$-bp region of the 16S rRNA gene universal primers were used: 16S_Start (5'AGAGTTTGATCMTGGCTCAG3') and 16S_Stop (5'AAGGAGGTGWTCCARCC3'). In brief, samples underwent an initial denaturation of $5 \mathrm{~min}$ at $98^{\circ} \mathrm{C}$ and 35 cycles of $10 \mathrm{~s}$ at $98^{\circ} \mathrm{C}$ (denaturation), $30 \mathrm{~s}$ at $60^{\circ} \mathrm{C}$ (annealing), $45 \mathrm{~s}$ at $72^{\circ} \mathrm{C}$ (extension), followed by $5 \mathrm{~min}$ at $72^{\circ} \mathrm{C}$ (final extension). The products were sequenced (Sanger's method). Sequences were aligned using DNA Baser v4.36.0. The isolate was identified using the EzTaxon server [60] on the basis of 16S rRNA sequence data. 


\section{Virulence genotyping}

Strains were subjected to the testing of 17 virulence genes related to pathogenicity of Salmonella. The genes invA, sipB, prgH, spaN, orgA, tolC, iroN, sitC, lpfC, sifA, sopB, pefA, spvB, spiA, pagC, $c d t B$ and msgA were targeted by three multiplex-PCR reactions using the protocol given below according to literature [58] with author's modifications. The list of the primers used in this study (Genomed, Poland) and VGs functions are presented in Table 2. The cycling conditions for all three reactions were the same and set as follows: $95^{\circ} \mathrm{C}$ for 5 min and 30 cycles of denaturation $\left(30 \mathrm{~s}, 94^{\circ} \mathrm{C}\right)$, annealing $\left(30 \mathrm{~s}, 66.5^{\circ} \mathrm{C}\right)$, extension steps $\left(2 \mathrm{~min}, 72^{\circ} \mathrm{C}\right)$, and final extension $\left(10 \mathrm{~min}, 72^{\circ} \mathrm{C}\right)$. PCR amplifications of each type of reaction were performed with a DNA Thermal Cycler T100 (Bio-Rad, USA).

\section{Gel electrophoresis, visualization, and analysis of $P C R$ amplification products}

The amplified products from all types of the PCR reactions were resolved on a $2 \%$ or $0.8 \%$ agarose gel (SigmaAldrich, USA) and visualized with Midori Green DNA

Table 2 Primers used in virotyping PCR reactions, with their sequence, size of ampliconsand biological function of targeted genes

\begin{tabular}{|c|c|c|c|}
\hline Gene target & Primer sequence & Amplicon size (bp) & Function of gene \\
\hline \multirow[t]{2}{*}{ invA } & F-CTGGCGGTGGGTTTTGTTGTCTTCTCTATT & \multirow[t]{2}{*}{1070} & \multirow[t]{2}{*}{ Host recognition/invasion } \\
\hline & R-AGTTTCTCCCCCTCTTCATGCGTTACCC & & \\
\hline \multirow[t]{2}{*}{$\operatorname{org} A$} & F-TTTTGGCAATGCATCAGGGAACA & \multirow[t]{2}{*}{255} & \multirow[t]{2}{*}{ Host recognition/invasion } \\
\hline & R-GGCGAAAGCGGGGACGGTATT & & \\
\hline \multirow[t]{2}{*}{$\mathrm{prgH}$} & F-GCCCGAGCAGCCTGAGAAGTTAGAAA & \multirow[t]{2}{*}{756} & \multirow[t]{2}{*}{ Host recognition/invasion } \\
\hline & R-TGAAATGAGCGCCCCTTGAGCCAGTC & & \\
\hline \multirow[t]{2}{*}{ spaN } & F-AAAAGCCGTGGAATCCGTTAGTGAAGT & \multirow[t]{2}{*}{504} & \multirow{2}{*}{$\begin{array}{l}\text { Entry into nonphagocytic cells, } \\
\text { killing of macrophages }\end{array}$} \\
\hline & R-CAGCGCTGGGGATTACCGTTITG & & \\
\hline \multirow[t]{2}{*}{ tolc } & F-TACCCAGGCGCAAAAAGAGGCTATC & \multirow[t]{2}{*}{161} & \multirow[t]{2}{*}{ Host recognition/invasion } \\
\hline & R-CCGCGTTATCCAGGTTGTTGC & & \\
\hline \multirow[t]{2}{*}{$\operatorname{sip} B$} & F-GGACGCCGCCCGGGAAAAACTCTC & \multirow[t]{2}{*}{875} & \multirow{2}{*}{$\begin{array}{l}\text { Entry into nonphagocytic cells, } \\
\text { killing of macrophages }\end{array}$} \\
\hline & R-ACACTCCCGTCGCCGCCTTCACAA & & \\
\hline \multirow[t]{2}{*}{ sitC } & F-CAGTATATGCTCAACGCGATGTGGGTCTCC & \multirow[t]{2}{*}{768} & \multirow[t]{2}{*}{ Iron acquisition } \\
\hline & R-CGGGGCGAAAATAAAGGCTGTGATGAAC & & \\
\hline \multirow[t]{2}{*}{ pagc } & F-CGCCTITICCGTGGGGTATGC & \multirow[t]{2}{*}{454} & \multirow[t]{2}{*}{ Survival within macrophage } \\
\hline & R-GAAGCCGTTTATTTTGTAGAGGAGATGTT & & \\
\hline \multirow[t]{2}{*}{$m s g A$} & F-GCCAGGCGCACGCGAAATCATCC & \multirow[t]{2}{*}{189} & \multirow[t]{2}{*}{ Survival within macrophage } \\
\hline & R-GCGACCAGCCACATATCAGCCTCTTCAAAC & & \\
\hline \multirow[t]{2}{*}{ spiA } & F-CCAGGGGTCGTTAGTGTATTGCGTGAGATG & \multirow[t]{2}{*}{550} & \multirow[t]{2}{*}{ Survival within macrophage } \\
\hline & R-CGCGTAACAAAGAACCCGTAGTGATGGATT & & \\
\hline $\operatorname{iroN}$ & F-ACTGGCACGGCTCGCTGTCGCTCTAT & 1205 & Iron acquisition \\
\hline & R-CGCTTTACCGCCGTTCTGCCACTGC & & \\
\hline sopB & F-GGACCGGCCAGCAACAAAACAAGAAGAAG & 220 & Host recognition/invasion \\
\hline & R-TAGTGATGCCCGTTATGCGTGAGTGTATT & & \\
\hline IpfC & F-GCCCCGCCTGAAGCCTGTGTTGC & 641 & Host recognition/invasion \\
\hline & R-AGGTCGCCGCTGTTGAGGTTGGATA & & \\
\hline$c d t B$ & F-ACAACTGTCGCATCTCGCCCCGTCATT & 268 & Host recognition/invasion \\
\hline & R-CAATTTGCGTGGGTTCTGTAGGTGCGAGT & & \\
\hline sifA & F-TTTGCCGAACGCGCCCCCACACG & 449 & Filamentous structure formation \\
\hline & R-GTTGCCTTTTCTTGCGCTTTCCACCCATCT & & \\
\hline pefA & F-GCGCCGCTCAGCCGAACCAG & 157 & Host recognition/invasion \\
\hline & R-GCAGCAGAAGCCCAGGAAACAGTG & & \\
\hline$s p \vee B$ & F-CTATCAGCCCCGCACGGAGAGCAGTIITIA & 717 & Growth within host \\
\hline & R-GGAGGAGGCGGTGGCGGTGGCATCATA & & \\
\hline
\end{tabular}


(Nippon Genetics, Germany) under UV light using a Gel Doc camera system (Bio-Rad, USA) and analyzed with Quantity One software (Bio-Rad, USA). PCR assays were repeated twice to confirm the correctness of the assignment of the investigated strains to their respective patterns.

\section{Pulsed-field gel electrophoresis (PFGE)}

All bacterial isolates were fingerprinted by the PFGE method, using the PulseNet protocol developed by Centers for Diseases Control and Prevention [61]. Chromosomal DNA was subjected to restriction analysis with application of XbaI enzyme (Thermo Fisher Scientific, USA). PFGE analysis was conducted with CHEF DR III PFGE apparatus (Bio-Rad, USA). DNA separation was performed with the following parameters: $1 \%$ agarose gel (Prona Agarose) on $0.5 \mathrm{M}$ Tris-Borate-EDTA buffer at $14^{\circ} \mathrm{C}$ for $19 \mathrm{~h}$ at $6.0 \mathrm{~V} / \mathrm{cm}(200 \mathrm{~V})$. Pulse time was ranging of $2.2-63.8 \mathrm{~s}$. The gels were stained with SYBR $^{\circ}$ Safe - DNA Gel Stain (Thermo Fisher Scientific, Germany) and band patterns were visualized under UV light and photographed using a Gel Doc camera system (Bio-Rad, USA). Molecular Weight Marker ProMegaMarkers ${ }^{\bullet}$ Lambda Ladders was used for analysis (Promega, USA). PFGE patterns were analyzed via visual assessment and the dendrograms were generated with UPGMA method using on-line software http://insilico.ehu.es/.

\section{GLC-MS/MS analysis}

\section{Preparation of samples for GLC-MS/MS analysis}

Samples for the analysis of NeuAc content were prepared according to Pawlak et al. [37]. In brief, bacteria and internal standard (perseitol, Koch-Light Laboratories Ltd., UK) were placed in a reaction tube and lyophilized. After lyophilization samples were methanolysed, evaporated and acetylated. After acetylation the samples were dried and dissolved in ethyl acetate (POCh, Poland). For GLC-MS/MS analysis $1 \mu \mathrm{l}$ was taken. Samples of Hafnia alvei PCM 2386 with confirmed presence of NeuAc in the O-antigen [35] were used as a control.

\section{GLC-MS/MS analysis}

Thermo FOCUS GC with ITQ 700 ion trap detector with external ionization (column: Restek, USA, Rxi - 5 $\mathrm{ms}, 30 \mathrm{~m}, 0.25 \mathrm{~mm}$ ID) was used for sample analysis by GLC-MS/MS. For MS/MS analysis primary ion $m / z 446$ was isolated and fragmented. The secondary fragment of $\mathrm{m} / \mathrm{z} 386$ was used for the quantitation of NeuAc derivative in the sample $[28,62]$.

\section{Additional file}

Additional file 1: Figure S1-S6. The electrophoregrams of amplification products of the tested virulence genes. (PDF $332 \mathrm{~kb}$ )

\section{Abbreviations}

GLC-MS/MS: Gas-liquid chromatography/tandem mass spectrometry; LPS: Lipopolysaccharide; MALDI-TOF MS: Matrix assisted laser desorption/ ionization time-of-flight mass spectrometry; NeuAc: Sialic acid;

NTS: Nontyphoidal Salmonella strains; PCM: Polish Collection of Microorganisms; PCR: Polymerase chain reaction; PFGE: Pulsed-field Gel Electrophoresis; RAS: Reptile-associated salmonellosis; REPAS: Reptile-exoticpet associated salmonellosis; SPI: Salmonella pathogenicity islands; VGs: Virulence-associated genes

\section{Acknowledgements}

The authors thank: Prof. Andrzej Gamian (Polish Academy of Sciences, Wrocław, Poland) for the $\mathrm{H}$. alvei strain from the Polish Collection of Microorganisms; Marek Pastuszek for help in collecting material from reptiles; dr Emil Paluch for the contribution in preliminary studies; Dialab Laboratory (Wrocław, Poland) for S. Enteritidis strains; National Veterinary Research Institute (Puławy, Poland) and National Salmonella Centre (Gdańsk, Poland) for help in serotyping of Salmonella strains isolated from reptiles.

\section{Authors' contributions}

$\mathrm{BD}, \mathrm{MKsiążczyk}$, and EK performed experiments and analyzed the data. KR, MKuczkowski, AWB and AKK prepared samples and helped in laboratory analysis. BD, KK, AKK and RR helped to collect and identify the clinical and environmental bacterial strains. BD, AW, JR and GBP contributed to experimental design and supervised the study. BD, MKsiążczyk, EK, JR and GBP drafted the manuscript. All authors read, commented on and approved the final version of the manuscript.

\section{Funding}

The project was financed from the National Science Center Grant No DEC2013/11/N/NZ9/00069. The funding agencies had no direct role in the conduct of the study, the collection, management, interpretation of the data, preparation or approval of the manuscript.

\section{Availability of data and materials}

The datasets analyzed in the present study are available from the first and corresponding author on reasonable request. Additional supporting files can be found in the supplementary material section.

Ethics approval and consent to participate

Not applicable.

\section{Consent for publication}

Not applicable.

\section{Competing interests}

The authors declare that they have no competing interests.

\section{Author details}

${ }^{1}$ Department of Microbiology, Faculty of Biological Sciences, University of Wrocław, 51-148 Wrocław, Poland. ${ }^{2}$ Department of Immunology of Infectious Diseases, Hirszfeld Institute of Immunology and Experimental Therapy, Polish Academy of Sciences, 53-114 Wrocław, Poland. ${ }^{3}$ Department of Epizootiology and Clinic of Birds and Exotic Animals, Wrocław University of Environmental and Life Sciences, 50-366 Wrocław, Poland. "Wrocław ZOO, 51-618 Wrocław, Poland.

Received: 12 September 2018 Accepted: 23 July 2019

Published online: 02 September 2019

\section{References}

1. Salmonella homepage CDC. https://www.cdc.gov/salmonella/. Accessed 27 June 2018

2. Antigenic formulae of the Salmonella serovars. http://www.scacm.org/free/ Antigenic\%20Formulae\%20of\%20the\%20Salmonella\%20Serovars\%202007\%2 09th\%20edition.pdf. Accessed 27 June 2018.

3. Biuletyny, meldunki, informacje epidemiologiczne. http://wwwold.pzh.gov. pl/oldpage/epimeld/index_p.html\#04. Accessed 27 June 2018.

4. Pumberger W, Novak W. Fatal neonatal Salmonella Enteritidis sepsis. J Perinatol Off J Calif Perinat Assoc. 2000;20(1):54-6. 
5. Roll C, Schmid EN, Menken U, Hanssler L. Fatal Salmonella Enteritidis sepsis acquired prenatally in a premature infant. Obstet Gynecol. 1996;88:692-3.

6. Dhanoa A, Fatt QK. Non-typhoidal Salmonella bacteremia: epidemiology, clinical characteristics and its' association with severe immunosuppression. Ann Clin Microbiol Antimicrob. 2009;8:15.

7. OhAiseadha CO, Dunne OM, Desmond F, O'Connor M. Salmonella meningitis and septicaemia in an non-immunocompromised adult, associated with a cluster of Salmonella Enteritidis PT 14b, Ireland, November 2009. Euro Surveill. 2010;15(7):19489.

8. Silva C, Maloy S, Calva E. One health and food-borne disease: Salmonella transmission between humans, animals, and plants. Microbiol Spectr. 2014; 2(1):137-48

9. Warwick C, Lambiris AJ, Westwood D, Steedman C. Reptile-related salmonellosis. J R Soc Med. 2001;94(3):124-6.

10. Lukac M, Pedersen K, Prukner-Radovcic E. Prevalence of Salmonella in captive reptiles from Croatia. J Zoo Wildl Med Off Publ Am Assoc Zoo Vet. 2015;46(2):234-40

11. Ebani W. Domestic reptiles as source of zoonotic bacteria: a mini review. Asian Pac J Trop Med. 2017;10(8):723-8.

12. Hoelzer K, Moreno Switt Al, Wiedmann M. Animal contact as a source of human non-typhoidal salmonellosis. Vet Res. 2011:42(1):34.

13. Van Meervenne E, Botteldoorn N, Lokietek S, Vatlet M, Cupa A, Naranjo M, et al. Turtle-associated Salmonella septicaemia and meningitis in a 2-monthold baby. J Med Microbiol. 2009;58:1379-81.

14. Schneider L, Ehlinger M, Stanchina C, Giacomelli M-C, Gicquel P, Karger C, et al. Salmonella enterica subsp. arizonae bone and joints sepsis. A case report and literature review. Orthop Traumatol Surg Res. 2009:95(3):237-42.

15. Jafari M, Forsberg J, Gilcher RO, Smith JW, Crutcher JM, McDermott M, et al. Salmonella sepsis caused by a platelet transfusion from a donor with a pet snake. N Engl J Med. 2002;347(14):1075-8.

16. Pawlak A. Reptile-associated salmonellosis as an important epidemiological problem. Postępy Hig Med Dośw. 2014;68:1335-42.

17. Pees M, Rabsch W, Plenz B, Fruth A, Prager R, Simon S, et al. Evidence for the transmission of Salmonella from reptiles to children in Germany, July 2010 to October 2011. Euro Surveill Bull Eur Sur Mal Transm Eur Commun Dis Bull. 2013;18(46).

18. Schröter M, Roggentin P, Hofmann J, Speicher A, Laufs R, Mack D. Pet snakes as a reservoir for Salmonella enterica subsp. diarizonae (serogroup IIlb): a prospective study. Appl Environ Microbiol. 2004;70(1):613-5.

19. Kędzierska B. N-Acetylneuraminic acid: a constituent of the lipopolysaccharide of Salmonella Toucra. Eur J Biochem FEBS. 1978;91(2):545-52.

20. Gamian A, Jones C, Lipiński T, Korzeniowska-Kowal A, Ravenscroft N. Structure of the sialic acid-containing O-specific polysaccharide from Salmonella enterica serovar Toucra O48 lipopolysaccharide. Eur J Biochem FEBS. 2000;267(11):3160-7.

21. Gamian A, Romanowska A, Romanowska E. Immunochemical studies on sialic acid-containing lipopolysaccharides from enterobacterial species. FEMS Microbiol Immunol. 1992;4(6):323-8

22. Giammanco GM, Pignato S, Mammina C, Grimont F, Grimont PAD, Nastasi A, et al. Persistent Endemicity of Salmonella bongori 48:z35:- in southern Italy: molecular characterization of human, animal, and environmental isolates. J Clin Microbiol. 2002;40(9):3502-5.

23. Foster $\mathrm{N}$, Kerr $\mathrm{K}$. The snake in the grass-Salmonella arizonae gastroenteritis in a reptile handler. Acta Paediatr Oslo Nor 1992. 2005;94(8):1165-6.

24. Figueira MA, Ram S, Goldstein R, Hood DW, Moxon ER, Pelton SI. Role of complement in defense of the middle ear revealed by restoring the virulence of Nontypeable Haemophilus influenzae siaB mutants. Infect Immun. 2007;75(1):325-33.

25. Ram S, Sharma AK, Simpson SD, Gulati S, McQuillen DP, Pangburn MK, et al. A novel sialic acid binding site on factor $\mathrm{H}$ mediates serum resistance of Sialylated Neisseria gonorrhoeae. J Exp Med. 1998;187(5):743-52.

26. Ringenberg MA, Steenbergen SM, Vimr ER. The first committed step in the biosynthesis of sialic acid by Escherichia coli K1 does not involve a phosphorylated N-acetylmannosamine intermediate. Mol Microbiol. 2003; 50(3):961-75.

27. Bugla-Płoskońska G, Futoma-Kołoch B, Rybka J, Gamian A, Doroszkiewicz W. The role of complement activity in the sensitivity of Salmonella $\mathrm{O} 48$ strains with sialic acid-containing lipopolysaccharides to the bactericidal action of normal bovine serum. Pol J Vet Sci. 2010;13(1):53-62.

28. Bugla-Płoskońska G, Rybka J, Futoma-Kołoch B, Cisowska A, Gamian A Doroszkiewicz W. Sialic acid-containing lipopolysaccharides of Salmonella
O48 strains-potential role in camouflage and susceptibility to the bactericidal effect of normal human serum. Microb Ecol. 2010;59(3):601-13.

29. Bugla-Płoskońska G, Korzeniowska-Kowal A, Guz-Regner K. Reptiles as a source of Salmonella O48-clinically important bacteria for children: the relationship between resistance to normal cord serum and outer membrane protein patterns. Microb Ecol. 2011;61(1):41-51.

30. Piasecki T, Chrząstek K, Wieliczko A. Salmonella serovar spectrum associated with reptiles in Poland. Acta Vet Brno. 2014;83(4):287-94.

31. Zając M, Wasyl D, Różycki M, Bilska-Zając E, Fafiński Z, Iwaniak W, et al. Freeliving snakes as a source and possible vector of Salmonella spp. and parasites. Eur J Wildl Res. 2016;62(2):161-6.

32. Dera-Tomaszewska B. Salmonella serovars isolated for the first time in Poland, 1995-2007. Int J Occup Med Environ Health. 2012;25:294-303.

33. Serowary Salmonella określone w Krajowym Ośrodku Salmonella w latach 1995-1997 - Epidemiological Review. http://www.przeglepidemiol.pzh.gov. $\mathrm{pl} /$ serowary-salmonella-okreslone-w-krajowym-osrodku-salmonella-wlatach-1995-1997?lang=pl. Accessed 28 Nov 2017.

34. Zestawienie serowarów Salmonella występujących w Polsce - Przegląd Epidemiologiczny. http://www.przeglepidemiol.pzh.gov.pl/zestawienieserowarow-salmonella-wystepujacych-w-polsce?lang=en. Accessed 28 Nov 2017.

35. Gamian A, Romanowska E, Dabrowski U, Dabrowski J. Structure of the Ospecific, sialic acid containing polysaccharide chain and its linkage to the core region in lipopolysaccharide from Hafnia alvei strain 2 as elucidated by chemical methods, gas-liquid chromatography/mass spectrometry, and proton NMR spectroscopy. Biochemistry (Mosc). 1991;30(20):5032-8.

36. Dudek B, Krzyżewska E, Kapczyńska K, Rybka J, Pawlak A, Korzekwa K, et al. Proteomic analysis of outer membrane proteins from Salmonella Enteritidis strains with different sensitivity to human serum. PLoS One. 2016;11(10): e0164069.

37. Pawlak A, Rybka J, Dudek B, Krzyżewska E, Rybka W, Kędziora A, et al. Salmonella O48 Serum Resistance is Connected with the Elongation of the Lipopolysaccharide O-Antigen Containing Sialic Acid. Int J Mol Sci. 2017; 18(10):2022

38. Ozdemir K, Acar S. Plasmid profile and pulsed-field gel electrophoresis analysis of Salmonella enterica isolates from humans in Turkey. PLoS One. 2014:9(5):e95976.

39. de Jong $B$, Andersson $Y$, Ekdahl K. Effect of regulation and education on reptile-associated salmonellosis. Emerg Infect Dis. 2005;1 1(3):398-403.

40. Whitten T, Bender JB, Smith K, Leano F, Scheftel J. Reptile-associated salmonellosis in Minnesota, 1996-2011. Zoonoses Public Health. 2015;62(3): 199-208.

41. Vora NM, Smith KM, Machalaba CC, Karesh WB. Reptile- and amphibianassociated salmonellosis in childcare centers. United States Emerg Infect Dis. 2012:18(12):2092-4.

42. Voetsch AC, Van Gilder TJ, Angulo FJ, Farley MM, Shallow S, Marcus R, et al. FoodNet estimate of the burden of illness caused by nontyphoidal Salmonella infections in the United States. Clin Infect Dis Off Publ Infect Dis Soc Am. 2004;38(Suppl 3):S127-34.

43. Jang YH, Lee SJ, Lim JG, Lee HS, Kim TJ, Park JH, et al. The rate of Salmonella spp. infection in zoo animals at Seoul Grand Park, Korea. J Vet Sci. 2008;9(2):177-81.

44. Silva-Hidalgo G, Ortiz-Navarrete VF, Alpuche-Aranda CM, RendónMaldonado JG, López-Valenzuela M, Juárez-Barranco F, et al. Non-typhi Salmonella serovars found in Mexican zoo animals. Res Vet Sci. 2012;93(3): 1132-5.

45. Abba Y, Ilyasu YM, Noordin MM. Isolation and identification of bacterial populations of zoonotic importance from captive non-venomous snakes in Malaysia. Microb Pathog. 2017;108:49-54.

46. Corrente M, Madio A, Friedrich KG, Greco G, Desatio C, Tagliabue S, D'Incau M, Campolo M, Buonavoglia C. Isolation of Salmonella strains from reptile faeces and comparison of different culture media. J Appl Microbiol. 2004;96: 709-15.

47. Corrente M, Totaro M, Martella V, Campolo M, Lorusso A, Ricci M, Buonavoglia C. Reptile-associated salmonellosis in man. Italy Emerg Infect Dis. 2006;12:358-9.

48. Lindberg A, Andersson Y, Engvall A, Hjalt C- $\AA$, Stenson M, Svenungsson B. Strategy document on salmonellosis. Stockholm: The National Board of Health and Welfare; 1999.

49. Wikström VO, Fernström L-L, Melin L, Boqvist S. Salmonella isolated from individual reptiles and environmental samples from terraria in private households in Sweden. Acta Vet Scand. 2014;56:7. 
50. Murphy D, Oshin F. Reptile-associated salmonellosis in children aged under 5 years in south West England. Arch Dis Child. 2015;100(4):364-5.

51. Bauwens L, Vercammen F, Bertrand S, Collard J-M, De Ceuster S. Isolation of Salmonella from environmental samples collected in the reptile department of Antwerp zoo using different selective methods. J Appl Microbiol. 2006; 101:284-9.

52. Giner-Lamia J, Vinuesa P, Betancor L, Silva C, Bisio J, Soleto L, Chabalgoity $J A$, Puente JL, The Salmonella CYTED Network, Garcia-del Portillo F. Genome analysis of Salmonella enterica subsp. diarioznae isolates grom invasive human infections reveals enrichment of virulence-related functions in lineage ST1256. BMC Genomics. 2019;20:99.

53. Pedersen $\mathrm{K}$, Lassen-Nielsen A-M, Nordentoft S, Hammer AS. Serovars of Salmonella from captive reptiles. Zoonoses Public Health. 2009;56:238-42.

54. Sanyal D, Douglas T, Roberts R. Salmonella infection acquired from reptilian pets. Arch Dis Child. 1997;77:345-6.

55. Pornsukarom S, Thakur S. Horizontal dissemination of antimicrobial resistance determinants in multiple Salmonella serotypes following isolation from the commercial swine operation environment after manure application. Appl Environ Microbiol. 2017;83.

56. Ammari S, Laglaoui A, En-Nanei L, Bertrand S, Wildemauwe C, Barrijal S, et al. Isolation, drug resistance and molecular characterization of Salmonella isolates in northern Morocco. J Infect Dev Ctries. 2009:3:41-9.

57. Parker $C T$, Huynh S, Quiñones B, Harris $L$, Mandrell RE. Comparison of genotypes of Salmonella enterica Serovar Enteritidis phage type 30 and $9 c$ strains isolated during three outbreaks associated with raw almonds. Appl Environ Microbiol. 2010;76:3723-31.

58. Skyberg JA, Logue CM, Nolan LK. Virulence genotyping of Salmonella spp. with multiplex PCR. Avian Dis. 2006;50(1):77-81.

59. Krawiec M, Kuczkowski M, Kruszewicz AG, Wieliczko A. Prevalence and genetic characteristics of Salmonella in free-living birds in Poland. BMC Vet Res. 2015;11:15.

60. Kim O-S, Cho Y-J, Lee K, Yoon S-H, Kim M, Na H, et al. Introducing EzTaxone: a prokaryotic $16 \mathrm{~S}$ rRNA gene sequence database with phylotypes that represent uncultured species. Int J Syst Evol Microbiol. 2012;62(Pt 3):716-21.

61. Standard Operating Procedure for PulseNet PFGE of Escherichia coli O157: H7, Escherichia coli non-O157 (STEC), Salmonella serotypes, Shigella sonnei and Shigella flexneri. https:/www.cdc.gov/pulsenet/pdf/ecoli-shigellasalmonella-pfge-protocol-508c.pdf. Accessed 27 June 2018.

62. Rybka J, Gamian A. Determination of endotoxin by the measurement of the acetylated methyl glycoside derivative of Kdo with gas-liquid chromatography-mass spectrometry. J Microbiol Methods. 2006;64:171-84.

\section{Publisher's Note}

Springer Nature remains neutral with regard to jurisdictional claims in published maps and institutional affiliations.

Ready to submit your research? Choose BMC and benefit from:

- fast, convenient online submission

- thorough peer review by experienced researchers in your field

- rapid publication on acceptance

- support for research data, including large and complex data types

- gold Open Access which fosters wider collaboration and increased citations

- maximum visibility for your research: over $100 \mathrm{M}$ website views per year

At $\mathrm{BMC}$, research is always in progress.

Learn more biomedcentral.com/submissions 